\title{
Pengembangan Media Pembelajaran Program Linier Berbasis Geogebra di STMIK STIKOM INDONESIA
}

\author{
Ni Wayan Suardiati Putri ${ }^{1 \S}$, Kadek Suryati ${ }^{2}$ \\ ${ }^{1}$ Program Studi Teknik Informatika, STMIK STIKOM Indonesia \\ Email: suardiatiputri@stiki-indonesia.ac.id \\ ${ }^{2}$ Program Studi Teknik Informatika, STMIK STIKOM Indonesia \\ Email: kadek.suryati@stiki-indonesia.ac.id
}

\begin{abstract}
The type of research conducted is development research. The aim of this research is to produce a valid and practical learning media GeoGebra based program at STMIK STIKOM Indonesia. The model of development used is Model Plomp consisting of (1) initial investigation stage, (2) design stage, (3) realization stage/construction, (4) test, evaluation and revision, and (5) implementation. The research is only up to a limited trial, not implementation. Validity testing of content, design and media is carried out by experts in their fields. While practicality tests are measured through students' responses to the use of media. The results showed that the learning media were classified as valid and practical with an average value of validity test on content, design, and media respectively were 3.78, 3.43, and 3.57. As for the value of practicality tests conducted by students is $85.86 \%$.
\end{abstract}

Keywords: GeoGebra, media, learning, development, linear programs

\section{PENDAHULUAN}

Program Linier merupakan bagian dari ilmu matematika yang digunakan untuk mencari nilai optimum dari sebuah pertidaksamaan linier. Ilmu ini sangat penting digunakan dalam melakukan perhitungan untuk mencari nilai optimum dari persoalan pertidaksamaan linier. Pada jenjang perguruan tinggi, umumnya materi program linier diberikan kepada mahasiswa baik berupa mata kuliah tersendiri, ataupun disisipkan pada mata kuliah lain, misalnya mata kuliah matematika. Dengan mempelajari materi program linier, maka peserta didik mampu melakukan penghitungan untuk optimasi suatu kasus agar memperoleh keuntungan yang maksimal.

STMIK STIKOM Indonesia merupakan sebuah lembaga pendidikan di bidang teknologi komputer. Sebagai sebuah institusi pendidikan, STMIK STIKOM Indonesia menawarkan materi program linier yang disisipkan pada mata kuliah matematika. Matematika merupakan mata kuliah wajib yang harus ditempuh oleh mahasiswa. Program Linier menjadi ilmu yang penting untuk diketahui oleh mahasiswa karena dalam mengerjakan program komputer mahasiswa harus menyelesaikan suatu kasus dengan cara optimasi. Teknik optimasi pada materi program linier dapat 
diterapkan dalam pembangunan program komputer yang dilakukan. Namun demikian, program linier menjadi materi yang tidak diminati oleh mahasiswa. Hal ini dapat dilihat dari antusias mahasiswa dalam belajar program linier di kelas sangat kurang. Disamping itu materi program linier dinilai sebagai materi abstrak yang sangat sulit untuk diimplementasikan dalam kehidupan sehari-hari.

Media pembelajaran yang dibangun dapat memvisualisasikan persoalan persamaan linier sehingga dapat dilihat variabel yang saling mempengaruhi pada aplikasi GeoGebra. Media pembelajaran dibuat secara interaktif agar mahasiswa dapat berinteraksi. Mahasiswa dapat melakukan perubahan variabel dan melihat hasil perubahan yang dilakukannya secara langsung. Hal ini akan membuat mahasiswa semakin tertarik untuk mempelajari materi program linier. Pada penelitian ini dibuat pengembangan media pembelajaran program linier berbasis GeoGebra. GeoGebra adalah salah satu program aplikasi pembelajaran matematika yang cukup canggih, mendukung beragam topik matematika dan dapat digunakan secara gratis.Selain dapat diakses secara offline, media yang dibuat menggunakan Geogebra juga dapat diunggah ke internet dan dapat diakses secara online darimana saja dan kapan saja. Tujuan penelitian ini adalah untuk menghasilkan media pembelajaran program linier berbasis GeoGebra yang valid dan praktis untuk materi program linier di STMIK STIKOM Indonesia.

\section{DATA DAN METODE}

Jenis penelitian yang dilaksanakan adalah penelitian pengembangan, karena dalam penelitian ini dikembangkan media pembelajaran program linier berbasis GeoGebra di STMIK STIKOM Indonesia. Produk yang dihasilkan dalam penelitian ini adalah media pembelajaran program linier berbasis GeoGebra yang memenuhi kriteria valid dan praktis..

Pengembangan media dalam penelitian ini berpedoman pada prosedur pengembangan perangkat pembelajaran menurut Plomp. Model Plomp [1] terdiri dari 5 tahap yaitu tahap investigasi awal (prelimenary investigation), tahap desain (design), tahap realisasi/konstruksi (realization/ construction), dan tahap tes, evaluasi dan revisi (test, evaluation and revision), dan implementasi (implementation). Tahap implementasi pada penelitian ini tidak dilakukan. Penelitian ini hanya sampai melakukan ujicoba terbatas, yakni upaya untuk melakukan evaluasi dan revisi guna memperoleh media yang siap untuk diimplementasikan dalam lingkup yang lebih luas. Pada tahap tes, evaluasi, dan revisi digunakan uji validitas dan ujicoba lapangan.

1) Uji validitas

Prototype 1 yang dihasilkan pada tahap realisasi kemudian diuji validitasnya oleh Ahli Isi, Ahli Desain, dan Ahli Media. Uji validitas dilakukan berkaitan dengan kesesuaian rancangan perangkat dengan kriteria validitas media yang ditetapkan. Berdasarkan hasil uji validitas kemudian dilakukan revisi sehingga diperoleh media dalam bentuk prototype 2. Langkah validasi dilakukan hingga diperoleh prototype yang memenuhi kriteria valid.

2) Uji coba lapangan

Uji coba lapangan bertujuan untuk mengetahui kebermanfaatan media yang dihasilkan (kepraktisan media) terhadap kualitas media pembelajaran. Uji coba lapangan dilakukan dengan uji coba terbatas yaitu dengan angket respon mahasiswa terhadap media pembelajaran program linier yang sudah dibuat. Penilaian kepraktisan media dilakukan dengan menilai angket respons mahasiswa. 
Pengumpulan data pada penelitian ini dilaksanakan dengan melakukan validitas media dan kepraktisan media pembelajaran, yang secara detail dijelaskan sebagai berikut.

1). Validitas

Untuk uji validitas media, para Ahli Isi, Ahli Desain dan Ahli Media diberikan lembar validasi, dimana pada lembar validasi tersebut memuat beberapa aspek yang meliputi: Isi media, cara penyajian, dan bentuk fisik media. Dalam lembar validasi pendapat validator dikatagorikan menjadi empat, agar hasil yang didapatkan jelas valid atau tidak.

\section{Tabel 1 Katagori validasi}

\begin{tabular}{|l|l|}
\hline \multicolumn{1}{|c|}{ Katagori } & Skor \\
\hline Sangat Valid & 4 \\
\hline Valid & 3 \\
\hline Tidak Valid & 2 \\
\hline Sangat Tidak Valid & 1 \\
\hline
\end{tabular}

Validitas media dikumpulkan dengan cara menjumlahkan skor setiap butir deskriptor pada lembar validasi media untuk masing-masing validator, kemudian menentukan rata-rata skornya.

2). Kepraktisan Media pembelajaran

Data mengenai kepraktisan media yang dikembangkan diperoleh dari hasil pengamatan keterlaksanaan media pembelajaran, angket respons mahasiswa terhadap media pembelajaran.. Penilaian yang dilakukan dengan memberikan tanda centang $(\sqrt{ })$ pada kolom penilaian. Indikator penilaian pada angket respon mahasiswa dikatagorikan menjadi lima skala penilaian yaitu sangat baik (skor 5), baik (skor 4), cukup (skor 3), kurang (skor 2), dan sangat kurang (skor 1). Penilaian setiap kriteria akan diakumulasikan dan menjadi bahan pertimbangan terkait kelayakan media yang dikembangkan.

Data yang telah dikumpulkan selanjutnya diolah secara deskriptif. Kualitas media yang dihasilkan harus memenuhi aspek validitas, dan kepraktisan.

1). Validitas media pembelajaran

Untuk melihat validitas media yang dikembangkan dilakukan langkah-langkah sebagai berikut. 1). Pertama-tama menentukan rata-rata skor yang diperoleh dari pendapat masing masing validator. 2). Rata-rata skor yang diperoleh dari masing-masing validator dijumlahkan, kemudian dirata-ratakan kembali sampai diperolehnya rata-rata skor total. 3) Validitas media ditentukan dengan mengkonversi rata-rata skor total menjadi nilai kualitatif dengan menggunakan kriteria berikut [2].

Tabel 2 Kriteria Kevalidan Media

\begin{tabular}{|l|l|}
\hline Skor & Kriteria \\
\hline $3,5 \leq \mathrm{Sr} \leq 4,0$ & Sangat Valid \\
\hline $2,5 \leq \mathrm{Sr}<3,5$ & Valid \\
\hline $1,5 \leq \mathrm{Sr}<2,5$ & Tidak Valid \\
\hline $1,00 \leq \mathrm{Sr}<1,5$ & Sangat Tidak Valid \\
\hline
\end{tabular}

Keterangan : 
$\mathrm{Sr}=$ Rata-rata skor berdasarkan hasil validasi

$$
S r=\frac{\text { JumlahSkordariSemuaItem }}{\text { Banyak Item }}
$$

2). Kepraktisan Media Pembelajaran

Teknik analisis data deskriptif kuantitatif digunakan untuk mengolah data hasil angket respon mahasiswa. Rumus untuk mengolah data yang digunakan adalah seperti rumus (2) .

$$
\text { Persentase }(P)=\frac{\sum X}{\sum X i} x 100 \%
$$

dengan, $\sum \mathrm{X}$ adalah total skor dari responden dan $\sum \mathrm{Xi}$ adalah total skor ideal. Tingkat pencapaian produk pengembangan yang diukur berdasarkan hasil perhitungan persentase, kriterianya dapat dilihat pada Tabel 3 [3]. (Diadptasikan dari Karmila Putri, 2016)

Tabel 3 Konversi tingkat pencapaian

\begin{tabular}{|l|l|}
\hline Rentangan Nilai Kualifikasi & Keterangan \\
\hline $90 \% \leq \mathrm{P} \leq 100 \%$ & Sangat Baik \\
\hline $75 \% \leq \mathrm{P}<90 \%$ & Baik \\
\hline $65 \% \leq \mathrm{P}<75 \%$ & Cukup \\
\hline $55 \% \leq \mathrm{P}<65 \%$ & Kurang \\
\hline $0 \% \leq \mathrm{P}<55 \%$ & Sangat Kurang \\
\hline
\end{tabular}

\section{HASIL DAN PEMBAHASAN}

\section{Proses Pengembangan Media}

Proses pengembangan media pembelajaran program linier berbasis GeoGebra menggunakan prosedur pengembangan menurut Plomp. Namun, dalam penelitian ini hanya dilaksanakan sampai kegiatan uji coba terbatas yaitu suatu upaya untuk melakukan evaluasi dan revisi hingga diperoleh prototype final berupa media yang siap diimplementasikan dalam situasi sebenarnya. Tahap implementasi tidak dilaksanakan mengingat berbagai pertimbangan diantaranya: (1) keterbatasan waktu penelitian dan (2) memerlukan keterlibatan mahasiswa yang lebih banyak. Berdasarkan pertimbangan tersebut maka dalam penelitian ini dilaksanakan sampai tahap keempat. Masing-masing tahap pengembangan media yang dilaksanakan dalam penelitian ini diuraikan sebagai berikut.

Tahap pertama pengembangan media adalah tahap investigasi awal yang dilakukan oleh peneliti. Pada tahap ini dilakukan analisis situasi dan permasalahan yang terjadi pada mata kuliah program linier. Hasil investigasi awal menunjukkan bahwa belum tersedianya media pembelajaran program linier berbasis GeoGebra yang mampu membantu mahasiswa dalam memahami materi program linier. Media pembelajaran akan dibuat secara interaktif agar mahasiswa dapat berinteraksi dan mahasiswa dapat melakukan perubahan variabel serta melihat hasil perubahan yang dilakukannya secara langsung Setelah tahap pertama dilaksanakan kemudian dilanjutkan tahap kedua yaitu tahap desain. Pada tahap ini peneliti menyusun draft media dan instrumen yang diperlukan berdasarkan hasil investigasi awal yang telah dilakukan. Selanjutnya dilaksanakan tahap ketiga oleh peneliti, yaitu 
tahap realisasi/konstruksi. Pada tahap ini dilakukan realisasi draft yang telah disusun menjadi media yang masih berupa prototype 1. Setelah diperoleh prototype 1 selanjutnya dilakukan tahap tes, evaluasi, dan revisi yaitu menguji kualitas prototype 1 yang telah diperoleh. Uji kualitas prototype I dilakukan dengan melaksanakan uji validitas dan uji kepraktisan. Uji Validitas dilakukan oleh ahli terhadap konten, desain, dan media. Sedangkan uji keraktisan dilakukan oleh mahasiswa terhadap hasil penggunaan media yang diperoleh melalui kuisioner. Selanjutnya dilakukan evaluasi dan revisi oleh peneliti, yang selanjutnya menghasilkan prototype 2 dengan kategori valid, dan instrumen yang telah memenuhi kelayakan untuk digunakan. Prototype 2 yang valid selanjutnya diuji coba pada mahasiswa STMIK STIKOM Indonesia kelas mata kuliah Matematika dengan materi Program Linier.

Kegiatan uji coba dilakukan untuk mengetahui kepraktisan media yang dikembangkan. Mahasiswa menggunakan media pembelajaran di laboratorium yang sebelumnya diberikan penjelasan terlebih dahulu oleh dosen tentang tatacara penggunaan media. Setelah menggunakan media, selanjutnya mahasiswa mengisi angket respon untuk mengetahui tingkat kepraktisan media. Hasil dari angket respons menunjukkan bahwa media yang dikembangkan pada penelitian ini telah memenuhi kategori praktis. Setelah kegiatan uji coba, dilakukan revisi pada prototype 2 sehingga menjadi prototype final dari Media Pembelajaran Program Linier berbasis GeoGebra di STMIK STIKOM Indonesia. Media yang berupa prototype final diserahkan kepada STMIK STIKOM Indonesia yang menjadi tempat penelitian.

\section{Hasil Pengembangan Media Pembelajaran}

Media yang berhasil dikembangkan dalam penelitian ini yaitu Media Pembelajaran Program Linier Berbasis GeoGebra. Media pertama dan kedua ini berisi cara menentukan daerah hasil jawaban dari pertidaksamaan. Media kedua berisi tentang cara menentukan titik-titik kritis pada grafik program linier. Media yang dikembangkan disini telah melalui proses uji validasi dan uji coba lapangan, sehingga diperoleh media dalam bentuk prototype final yang siap diujicobakan lebih luas.

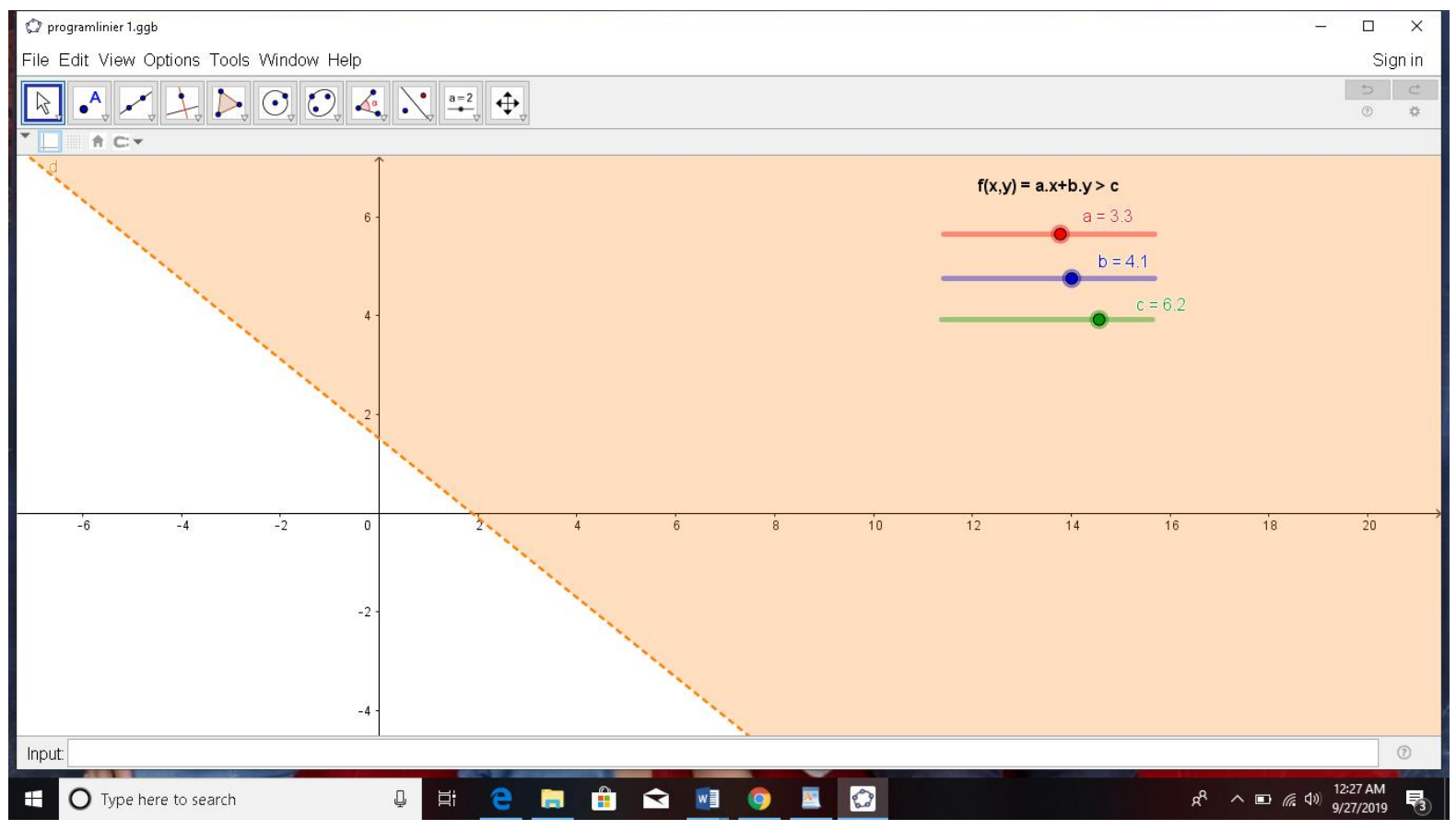

Gambar 2. Tampilan Media 1 


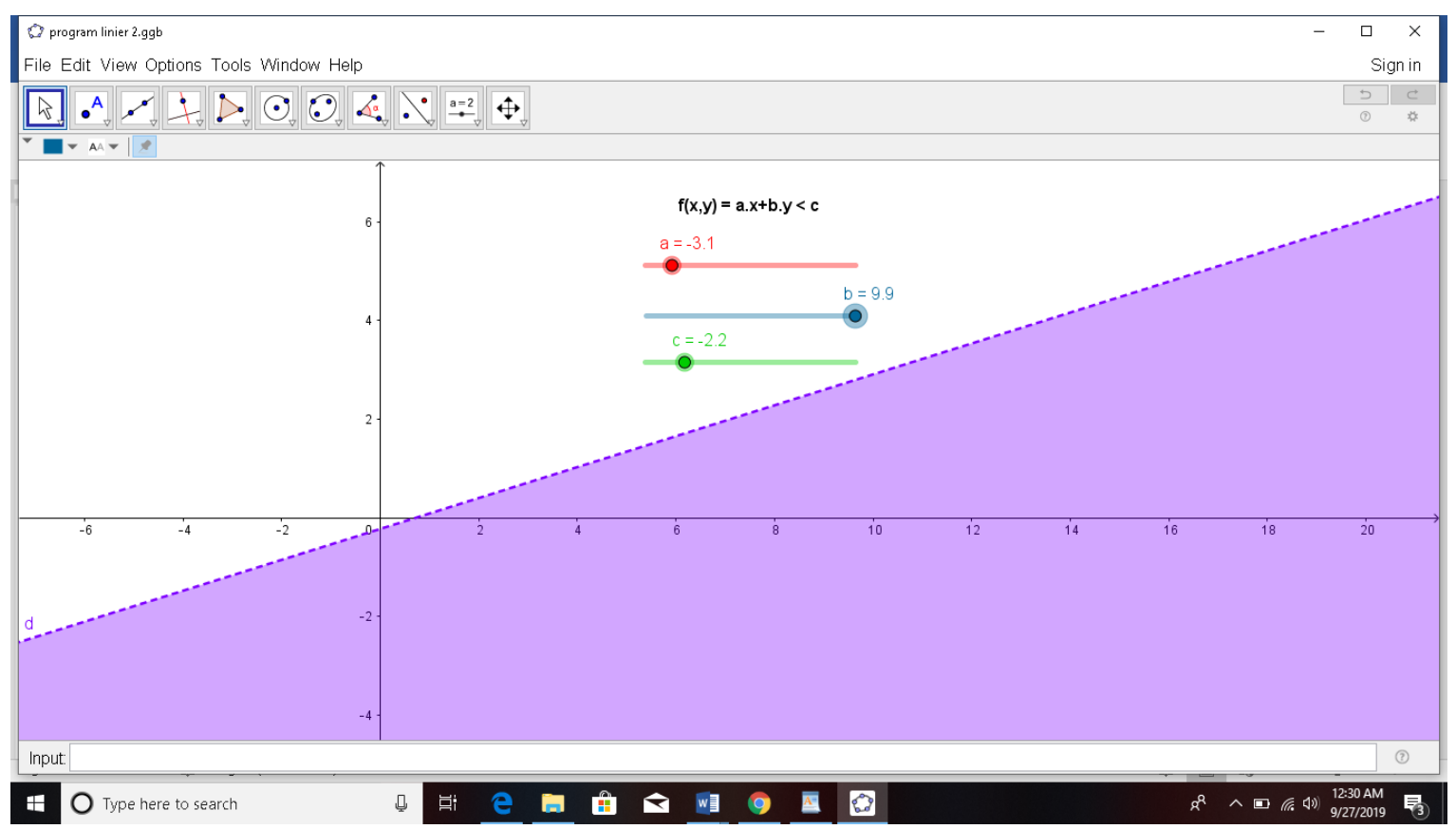

Gambar 3. Tampilan Media 2

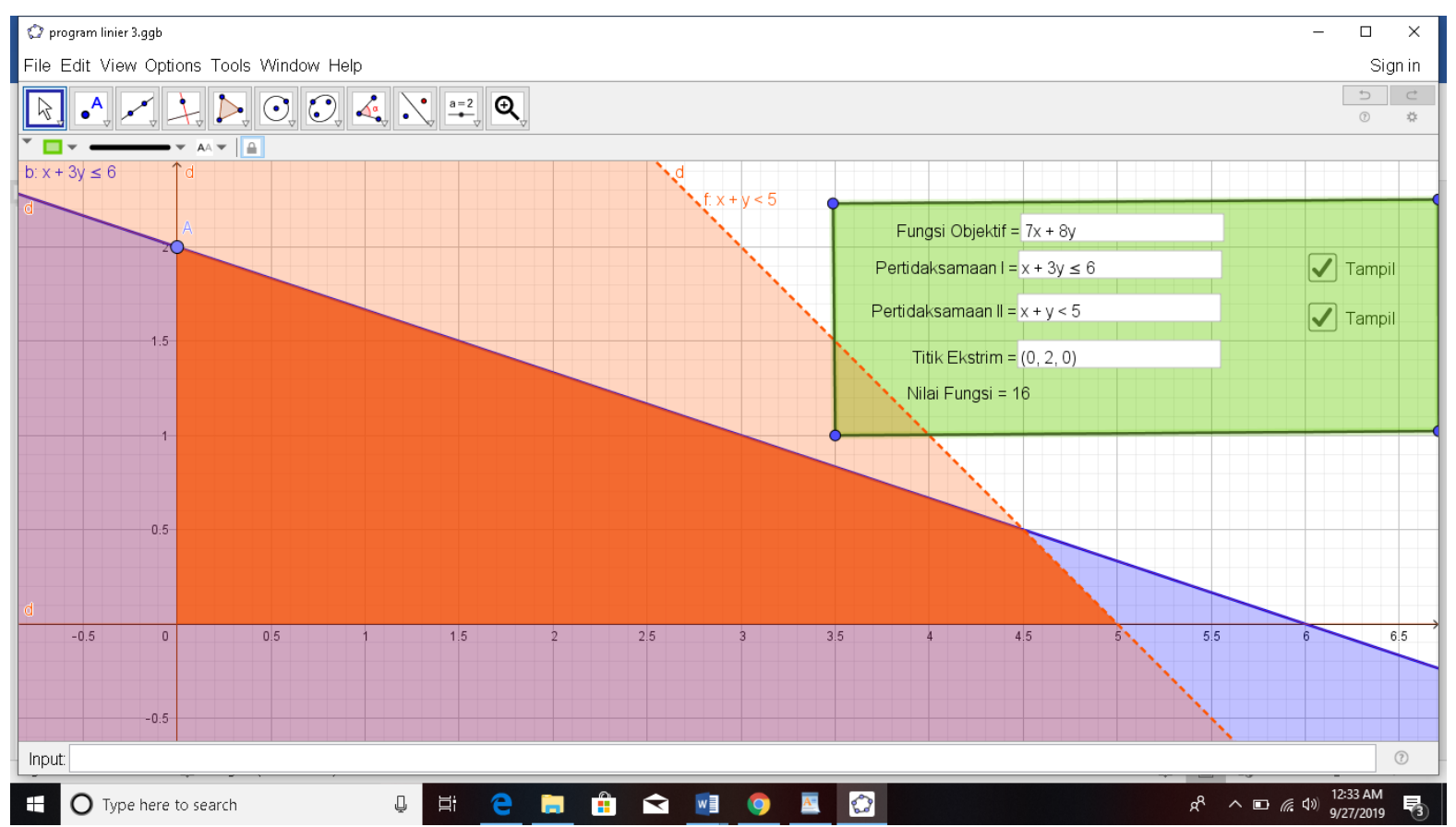

Gambar 4. Tampilan Media 3

Program linier merupakan salah satu materi pembelajaran matematika untuk menyelesaikan masalah-masalah yang bersifat linier, baik masalah penentuan nilai maksimum maupun nilai minimum. Materi prasyarat program linier antara lain sistem persamaan dua variabel dan sistem pertidaksamaan dua variabel. Pada media pertama dan kedua disajikan sistem pertidaksamaan dua variabel karena mahasiswa kadang sering keliru menentukan daerah penyelesaian dari pertidaksamaan, media tersebut menunjukkan bagaimana daerah penyelesaian dari pertidaksamaan 
tersebut dengan cara mahasiswa menggerakkan slider yang sudah tersedia. Pada media ketiga ditampilkan input box untuk menginput pertidaksaman yang diketahui, sehingga media memunculkan daerah penyelesaian untuk menemukan titik-titik ekstrim dengan cara menggeser titik A pada setiap titik - titik yang menjadi batas daerah penyelesaian, titik-titik tersebut akan dimasukan ke nilai fungsi tujuan yang sudah tertera di media, yang nantikan akan menemukan nilai maksimum atau minimum. Kelebihan media pembelajaran program linier berbasis GeoGebra yang dibuat dengan GeoGebra dapat memancing mahasiswa pada bagian Eksplorasi dari media pembelajaran program linier berbasis GeoGebra, mahasiswa dapat melihat daerah penyelesaian dari pertidaksamaan sehingga mahasiswa dapat mengkaitkan dugaan intuisinya dengan kebenaran yang ditampilkan pada media pembelajaran berbasis GeoGebra.

Pengukuran kualitas media pembelajaran ditinjau dari aspek kevalidan dan kepraktisan yang dikemukakan oleh Nieveen [4] (dalam Rochmad, 2012)

a. Validitas Media

Uji validitas bertujuan untuk memperoleh validitas dari media yang telah dikembangkan dalam bentuk prototype 1 . Uji validitas terhadap isi, desain dan media dilakukan oleh para ahli dibidangnya. Uji validitas ini masing-masing dilakukan oleh satu ahli (validator). Validator yang dimaksud adalah Dosen dari IKIP PGRI Bali untuk ahli Isi media, Dosen STMIK STIKOM Indonesia untuk Ahli Desain dan Ahli Media. Sebelum menilai media, validator melakukan penilaian terhadap instrumen penelitian, yang akhirnya diperoleh instrumen penelitian yang layak digunakan. Kemudian validator melakukan penilaian terhadap media yang dikembangkan. Validator memberikan skor sesuai dengan indikator dan deskriptor yang ada pada lembar validitas. Selanjutnya dikomparasi sehingga diperoleh rata-rata validitas yang, kemudian dikonversikan kedalam kategori-kategori validitas. Dari perhitungan validitas diperoleh validitas media sesuai dengan indikator yang diharapkan. Berdasarkan hasil uji validitas yang telah dilakukan diperoleh bahwa Media Pembelajaran Program linier Berbasis GeoGebra telah memenuhi kriteria validitas yang diharapkan. Hal ini berarti bahwa media yang dikembangkan telah memenuhi kriteria valid. sebab telah memenuhi memenuhi aspek validitas dengan rata-rata skor dari ahli isi sebesar 3,78 kategori sangat valid, dari ahli desain pembelajaran sebesar 3,43 kategori valid, dan dari ahli media sebesar 3,57 kategori sangat valid

Tabel 4 Rangkuman Hasil Analisis Validasi

\begin{tabular}{|l|l|l|l|}
\hline No & Validasi & Rata-rata Skor Validator & Katagori \\
\hline 1. & Validasi dari Ahli Isi & 3,78 & Sangat Valid \\
\hline 2. & Validasi dari Ahli Desain & 3,43 & Valid \\
\hline 3. & Validasi dari Ahli Media & 3,57 & Sangat valid \\
\hline
\end{tabular}

b. Kepraktisan Media

Pengujian kepraktisan Media diukur dari respons mahasiswa terhadap pengunaan media dalam pembelajaran. Hasil analisis respons mahasiswa terhadap penggunaan media menunjukkan 
respon mahasiswa sebesar $85,86 \%$ kategori baik berarti media praktis digunakan dalam pembelajaran program linier.

\section{SIMPULAN DAN SARAN}

Simpulan dari penelitian ini yaitu Media Pembelajaran Berbasis GeoGebra yang dikembangkan dalam penelitian ini dapat dikategorikan valid dan praktis. Valid tergambar dari hasil penilaian validator dimana validator menyatakan baik berdasarkan isi, desain maupun medianya. Praktis tergambar dari uji coba lapangan dimana semua mahasiswa dapat menggunakan media dengan baik. Berdasarkan hasil yang diperoleh dalam penelitian ini, dapat disarankan yaitu: Perlu dilakukan pengembangan dengan menggunakan model yang lain sebagai perbandingan dari model Plomp yang digunakan pada penelitian ini.

\section{DAFTAR PUSTAKA}

[1] N. Wayan, S. Putri, and I. M. Ardana, "PRESTASI DAN AKTIVITAS BELAJAR GEOMETRI SISWA e-Journal Program Pascasarjana Universitas Pendidikan Ganesha," ejournal Progr. Pascasarj. Univ. Pendidik. Ganesha, vol. 3, 2014.

[2] W. Sadra, "Pengembangan Model Pembelajaran Matematika Berwawasan Lingkungan dalam Pelatihan Guru Kelas 1 Sekolah Dasar,” UNESA, 2007.

[3] K. Putri, C. I M., and S. G, "PENGEMBANGAN MEDIA PEMBELAJARAN TRANSFORMASI BERBASIS GEOGEBRA," J. Wahana Mat. dan Sains, vol. 10, pp. 25-35, 2016.

[4] Rochmad, "Desain Model Pengembangan Perangkat Pembelajaran Matematika," J. Kreano, vol. 3, no. 1, pp. 59-72, 2012. 